\title{
Relationship Between Principal's Leadership Role, Subordinate Maturity and Work Motivation Towards Teacher's Discipline
}

\author{
Khoiru Nisa *, Aslamiah, Suhaimi \\ Master Program of Education Management, Universitas Lambung Mangkurat, Banjarmasin 70123, \\ Indonesia
}

Article history:

Submission November 2019

Revised June 2020

Accepted July 2020

*Corresponding author:

E-mail: nisakimmie@gmail.com

\begin{abstract}
The purpose of this study was to describe and analyze the indirect/direct role of the principal's leadership, subordinate maturity, work motivation, and discipline of teachers. This was a quantitative research with a correlational descriptive design. Data were obtained from 154 people through questionnaires. Furthermore, the data obtained were analyzed to test hypotheses using path analysis with multiple regression methods. The results showed that the Principal's indirect/direct Leadership Role, Subordinate Maturity, work motivation, and work discipline of teachers are in the moderate category. Efforts should be made to increase the level of maturity of subordinates, this can be done by involving low and middle-level teachers in various development programs, such as education and training, seminars, or if it is possible to provide learning tasks to teachers with low and moderate levels of maturity for raise the level of education to increase the maturity of their work

Keywords: The role of leadership, subordinate maturity, work motivation, work discipline
\end{abstract}

\section{Introduction}

A school as an educational institute needs the services of qualified teachers to face the ever-evolving changes associated with academics and to fulfill the demands of their positions. The existence of qualified educators/teachers is highly expected to produce a generation made up of competitive citizens.

According to Hoy and Miskel (2014), the quality of education is the result of an assessment associated with the process needed to develop the talents of students. However, one of the problems faced is the low quality of education at the primary level.

This problem is also faced by the 23 Elementary Schools in Takisung Sub-district. The issue associated with low-quality education needs to be of great concern because through educational institutions, human resources are produced. The quality of human resources plays an important role in determining the success of various physical and non-physical development sectors (Samsudin, 2014). Quality resources in the world of education are inseparable from the role of principals, teaching staff, administrators, supervisors, committees, and the community.

To improve the quality of human resources, educational institutions need to possess qualified teachers supported by proper management. Disciplinary rules are often a problem for teachers and employees in educational institutions. Many of them ultimately violate these rules and constantly seek for forgiveness from the regulators. These violated rules include inaccuracy with time, mismatch in academic planning/learning, and neglect in completing assigned tasks (Soeharto, 2016). Discipline is an obligation that needs to be obeyed, and its violation needs to be prohibited by every teacher or employee (Moenir, 2012). It is a social aspect that needs in-depth understanding and inner growth for the proper implementation of the applicable rules.

Discipline is also interpreted as an attitude of respect and obedience to written and unwritten regulations, which are carried out with sanctions administered on defaulters by the authority (Suwatno \& Priansa, 2016). Discipline provides a significant role in showing the level 
of teacher performance to achieve set educational goals. A leader plays an important role in upholding discipline. This category of people possesses the expertise or ability to influence others to carry out an activity following their desires and organizational goals. Leadership is essentially interpreted as the science and art of a person to influence others in achieving specified goals (Wahjosumidjo, 2013).

The educational activities in an agency are dependent on the discipline conducted by its members. Schools that foster discipline create individual values and norms, self-mastery, attitudes, and responsibilities for teachers. However, teachers' indiscipline in carrying out tasks such as coming to school late, not caring for students leads to low quality of education.

Discipline is also influenced by a good relationship with fellow employees, which makes them happy and calm while conducting their various work activities. Furthermore, discipline is achieved through legal guarantees in the form of laws and regulations, good cooperation, and the ability of leaders to motivate their subordinates (Samsudin, 2014).

The behavior that arises in a person or subordinate through motivation is driven by need (Wahjosumidjo, 2013). Therefore, need is the driving force of a person to achieve goals. Some things that arouse teacher work motivation include decent wages, a pleasant work atmosphere, opportunities for growth, recognition, and the need for achievement.

Furthermore, many factors affect teachers' discipline, such as safe and healthy working conditions, performance, motivation, subordinate maturity, and leadership style. However, this study only examines work discipline, which is influenced by motivation, subordinate maturity, and leadership style.

Work motivation is the ability of a person to achieve predetermined goals (Wahjosumidjo, 2013). Motivation is a change of energy in a person, which is marked by the appearance of feeling and preceded by a response to the existence of goals. The energy is the desire of someone to work to achieve goals.

One of the main factors for leadership effectiveness is identifying the maturity level of in- dividuals or groups to be influenced (Wahjosumidjo, 2013). The ability of subordinates to take responsibility for directing their behavior is known as maturity. The concept of maturity in a relationship consists of two elements, namely, ability and willingness (Wahjosumidjo, 2013). Its level in subordinates is low, middle, or high.

Leadership plays an important role in achieving the success of an organization because it affects the performance of its members (Kartono, 2016). It is a process where a person becomes a leader through continuous activities, therefore, they can influence their subordinates to achieve educational goals. Leadership is related to individual and technical abilities. Individual ability is closely related to human's natural zeal to become leaders, therefore everyone possesses the same opportunity to become a leader, with differing technical skills (Kartono, 2016).

Every institution needs a leader with unique technical abilities tailored to meet the scope of education. In this case, a School Principal is required to have the right technical skills in managing an institution, understand as well as describe the tasks and parts of the school organization. A school principal needs to be able to provide a charismatic leadership style, through examples, and by mobilizing/directing all stakeholders to achieve its goals.

Furthermore, leadership is described as a process that influences a cooperation ability to achieve set goals because it plays a central role in the dynamics of organizational life (Wahjosumidjo, 2013).

Leadership does not only affect the achievement of goals, but it also motivates the behavior of organizational members and influences the efforts to improve the group and work discipline. According to Rivai (2014), motivation is a collection of a series of attitudes and values possessed by someone that influences behavior to achieve specific goals.

Principals as education managers are required to be responsible for all components of the school, such as improving the academic quality that is oriented towards students, government, industries, and businesses. 
The teacher discipline in Takisung Sub-district indicates that some teachers possess a downward trend in work motivation as they often neglect assignments, fail to prepare lesson plans, arrive late to school, and do not correspond to the scheduled homecoming hours. When this is ignored, it has the ability to directly or indirectly affect the teaching and learning activities in schools. From these problems, this research is conducted to determine the Relationship between Leadership Roles, Subordinate Maturity, and Work Motivation towards the Teacher's Work Discipline in the State Elementary Schools in Takisung Sub-district.

\section{Material and Methods}

This study was a quantitative research with a correlational descriptive design. The sample in this study was 154 teachers from 23 public elementary schools in the District of Takisung.
Data collected through questionnaires. Furthermore, path analysis with multiple regression methods was used to analyze the data obtained.

\section{Results and Discussion}

In this research, we using HV agar media to isolate Actinomycetes from the termite's nest sample. Its classify into nutrient-poor media therefore not many other microorganisms are able to live and utilize nutrients available in the media other than Actinomycetes bacterial group. In the process of Actinomycetes.

\section{Isolation of Actinomycetes from termite's nest sample}

The results showed that there were direct and indirect relationships of Leadership Roles, Subordinate Maturity, and Work Motivation towards Teacher's Work Discipline in the State Elementary Schools in Takisung Sub-district, as shown in the following figure:

Table 1. Mean, standard deviation and stage

\begin{tabular}{|c|c|c|c|c|}
\hline \multicolumn{2}{|l|}{ Variable } & Mean & \multirow{2}{*}{$\begin{array}{c}\text { Standard Deviation } \\
3.85982\end{array}$} & \multirow{2}{*}{$\begin{array}{c}\text { Stage } \\
\text { Moderate }\end{array}$} \\
\hline $\begin{array}{l}\text { The Role of the } \\
\text { Leadership }\end{array}$ & Principal's & 65.71 & & \\
\hline Subordinate Maturity & & 81.61 & 4.21220 & Moderate \\
\hline Work Motivation & & 88.83 & 4.60388 & Moderate \\
\hline Teacher's Work Discipline & & 113.84 & 6.25960 & Moderate \\
\hline \multicolumn{5}{|c|}{$\begin{array}{l}\text { Source: SPSS Output Results, } 2019 \\
\text { Table 2: Summary of path analysis results }\end{array}$} \\
\hline Variable & $\begin{array}{c}\text { Path } \\
\text { Coefficient } \\
\text { Value }\end{array}$ & Significance & $\begin{array}{c}\text { Interpretatio } \\
\mathrm{n}\end{array}$ & Description \\
\hline $\mathrm{X} 1$ and $\mathrm{Z}$ & 0.770 & 0.000 & High & Significant \\
\hline $\mathrm{X} 2$ and $\mathrm{Z}$ & 0.734 & 0.000 & High & Significant \\
\hline $\mathrm{X} 1$ and $\mathrm{Y}$ & 0.822 & 0.000 & Very high & Significant \\
\hline $\mathrm{X} 2$ and $\mathrm{Y}$ & 0.627 & 0.000 & High & Significant \\
\hline $\mathrm{Z}$ and $\mathrm{Y}$ & 0.824 & 0.000 & Very high & Significant \\
\hline X1 ?Z?Y & 0.634 & 0.000 & High & Significant \\
\hline $\mathrm{X} 2$ ? ?Z目Y & 0.605 & 0.000 & High & Significant \\
\hline
\end{tabular}

Source: Path Analysis 


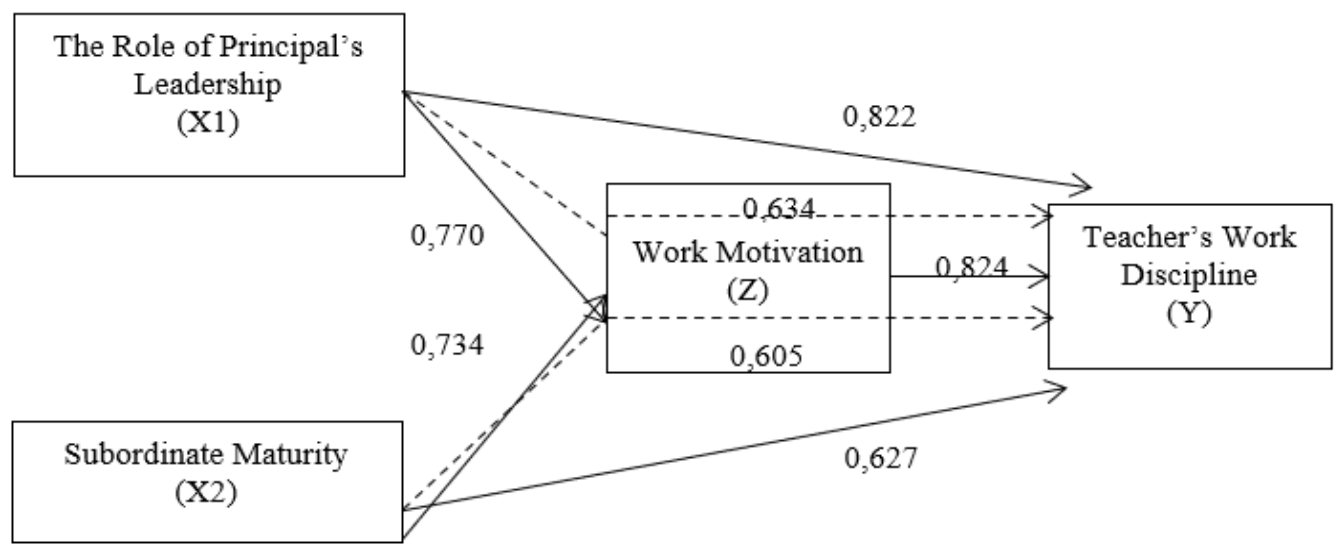

Figure 1: Results of the Analysis of the Relationship between the Role of Principal's Leadership (X1), Subordinate Maturity (X2), Work Motivation (Z) and Teacher's Discipline (Y); Processed by reseachers

Description of the principal's leadership role, maturity of subordinates, work motivation, and discipline

The role of the principal's leadership

This is one of the determining factors in improving the quality of education in schools. This is seen from the various steps adopted by the principal in encouraging and motivating school members to realize its vision, mission, and goals, which are implemented in a planned and gradual manner. The principal is responsible for the management of education on a micro level, which is directly related to the learning process in schools (Suhaimi, 2019). The abovementioned attributes are important in line with the increasingly complex demands of the principal's duties, which require efficient and effective performance support. Therefore, an ideal school principal is someone with strong management and leadership abilities to make decisions take initiatives to improve the quality of schools.

The mean total value of a Principal's Leadership Role, pragmatic, and sub-variables obtained mean values of $3.46,33.46$, and 3.63 , which were all in the high category. This means that the average elementary school teacher in Takisung Sub-district considers the school principal had new ideas that were useful for its progress. The results of this study are in line with the research of Aslamiah \& Irawati (2019) which states that the leadership role of high school principals can be seen from the balance of principals in carrying out all their roles when leading schools, be they roles as educators, managers, administrators, supervisors, supervisors, leaders, reformers as well as driving. If all of these roles can be carried out properly and in balance, the principal can be said to have carried out his role as a leader well.

Sub-variable value as an educator had the smallest mean value of 3.32, which is included in the high category, this means that the average considers that the principals can carry out their role as an educator properly, by guiding teachers, students and staff towards a better direction, by improving their performance and learning outcomes.

\section{Subordinate maturity of teachers}

This is the ability and willingness of people to take responsibility for directing their behavior. The concept of maturity in a relationship consists of two elements, namely, ability and willingness (Wahjosumidjo, 2013). Maturity of ability is associated with knowledge or skills obtained from education, training, and experience. While that of desire is associated with self-confidence and motivation to carry out an activity (Thoha, 2015). The level of subordinate maturity in this study was measured through ability and willingness.

The results showed that the subordinate maturity of teachers was in the high category. This is because elementary school teachers in Takisung Sub-district, Tanah Laut Regency 
have a high ability and willingness to carry out their duties and obligations properly.

\section{Teacher's motivation}

Work motivation is a morale booster. It is interpreted as an act that encourages teachers to be enthusiastic in teaching (Maslow, 2016). Work scores are reflected in internal and external motivation. The results showed that the work motivation of elementary school teachers in Takisung Sub-district was in the moderate category.

The mean total value of the teacher's work motivation variable is 3.48 and in the high category. The sub variable of external motivation obtains the highest mean value of 3.48 in the high category. This means that the average teacher at the State Elementary School in the Takisung Sub-district has a high external motivation, which is characterized by efforts to meet work needs from the demonstrated achievements. The external motivation is also seen from the answers of several respondents who stated that they work to acquire incentives and attention from superiors. Besides, teachers also carry out work by establishing good relationships with colleagues and helping each other.

The sub variable of internal motivation obtains the lowest mean value of 3.45 in the high category. This means that the institutions have good internal motivation, and their teachers have responsibilities and interests in their work. This is evidenced by their efforts to properly carry out a task that arises due to the teachers' motivation to show the best achievements in teaching. The results of this study are in line with (Rahmawati et al., 2019) which states that high motivation is formed due to the existence of a commitment between encouragement that comes from within the self from the teacher itself with encouragement that comes from outside the teacher, for example, from the organization or environment around. The more positive internal impulses owned by someone, the better the motivation that will be formed on the person concerned. Likewise with external impulses, if external impulses are positive, of course the motivation formed in that person will also be good.

\section{Teacher's working discipline}

The teacher's work discipline in this study was measured through goals and abilities, attendance list, leadership examples, retribution, justice, clinging oversight, and legal sanctions.

The average total value of the teacher's work discipline was 3.45 , while the sub variable of the leader obtained the highest mean value of 3.54. This value was included in the high category, which means that the majority of teachers in the State Elementary Schools in Takisung Sub-district, Tanah Laut Regency, considered the principal as a role model.

Sub variable of penalty sanctions obtained the lowest mean value of 3.35 , which was included in the high category. This means that penalties were imposed on teachers for committing disciplinary violations.

\section{Direct relationship of the principal's leader- ship role with teacher's work motivation}

The results of the path analysis between the principal's leadership roles and the work motivation of teachers showed 0.770 , which indicates a strong relationship between the variables. Teacher work motivation is dependent on the principal's leadership. The key to the success of a leader in mobilizing teachers or subordinates lies in their ability to understand the factors of work motivation to be an effective driver. These findings are in line with the research carried out by Jajang \& Mahri (2011) which stated that the principal's leadership and teacher work motivation have a significant relationship with correlating values of 0.8131 .

The principal's support can ensure teachers remain highly motivated. Effective personal support from school principals in increasing teacher work motivation provides opportunities for subordinates to use their potential and ensure the achievement of individual goals. The school principal believes in the ability to build good motivation and improve work effectiveness and efficiency, therefore the subordinates can be creative to realize good quality education (Sabirin, 2012) dan (Purwanti, 2013). The principal's ability to build motivation is one way to improve the quality of education due to its correlation with teacher performance. The results of the (Septiana et al., 2013) study, concluded that the principal's leadership and work 
motivation had a significant effect on teacher performance.

Principals need to encourage and motivate teachers by giving awards through praises and recognition. It is also important for principals to create facilities that meet and support the needs of teachers by paying attention to increase their morale and work motivation. These facilities include teaching materials, learning resources, and other media. Therefore, the principal's leadership is thought to be related to work motivation.

The results of this study are in line with previous research conducted by Aslamiah \& Irawati (2019) which stated that there was a relationship between the role of the principal and teacher work motivation. Similarly, Suhaimi (2019) (2019), stated that there was a direct relationship between leadership and teacher work motivation. Syarwani (2018) also stated that leadership influences teacher work motivation.

\section{Direct relationship of subordinate maturity with teacher's work motivation}

The results of the analysis of the path between the maturity of subordinates and work motivation show the number 0.539, which means that there is a significant but moderate relationship.

The maturity of an organizational member is not based on psychological maturity, but rather describes the desire, willingness, and ability of organizational members to carry out tasks (Nawawi, 2015).

People with high maturity possess a greater motivation to carry out their duties and responsibilities properly, which is inversely proportional to those with low maturity levels. This is because these responsibilities are sometimes hampered by the inability of the employee to carry out the task using the right procedures. It also causes low work motivation in employees with a low maturity level.

When associated with the world of education, a teacher with a high level of maturity certainly carries out the task properly due to the motivation to carry out these tasks by organizing education through maximum teaching and learning processes.

\section{Direct relationship of the principal's leader role with the teacher's working discipline}

The results of path analysis between the Principal's Leadership Roles and the Achievement of State Elementary Schools in Takisung Sub-district showed the number of 0.822 , which means that there is a high or strong relationship between both parties.

The results of this study are in line with $\mathrm{Su}$ trisno, 2016), which stated that leaders have a direct influence on the attitudes obtained by employees. These are determined by the leader from the climate or leadership atmosphere. Therefore, to obtain good discipline, the leader needs to provide proper leadership skills.

Furthermore, Sutrisno (2016) stated that a leader's example is very important because all teachers always pay attention to how leaders enforce self-discipline and control themselves both from words, deeds, and attitudes capable of harming the established discipline rules. When a member violates discipline, the leader needs to be brave enough to take action. By taking action against disciplinary offenders, following existing sanctions, all members of the organization tend to feel protected and guaranteed. Therefore, it forms a commitment to each member of the organization not to violate discipline.

The relationship between leadership roles and work discipline is also seen from the inherent supervision aspects of the leader. The most suitable individual to carry out the supervision of the discipline is the leader of the organization. This is because they are close to their subordinates.

\section{Direct relationship of subordinate maturity with teacher's working discipline}

The results of the path analysis between the subordinate maturity and the achievement of State Elementary School in Takisung Sub-district showed 0.627, which means that there is a significant but moderate relationship between the variables of subordinate maturity and the teacher's work discipline.

The work discipline of a worker in an organization is one part of the maturity of the personality to achieve set goals. An individual's 
work discipline is seen from the use of appropriate working time, role models of leaders, use of infrastructure, adherence to work rules, and set procedures. Furthermore, their obedience in carrying out the work also tends to affect the discipline of employees.

The results of this study are in line with the research of Suriansyah (2018) which states that the role of the principal is needed in the management of an educational institution because the implementation of the principal's role will shape conducive school conditions including creating work discipline for teachers. (Aslamiah et al. (2019) states that there is a positive and significant direct effect of the leadership of the principal on the discipline of teacher work, which means the better the implementation of the principal's role, the higher and better the discipline of the teacher. this is because the principal's leadership is an important factor in developing teacher work discipline. the principal as a leader has an important role in mobilizing, directing, protecting all school members, especially teachers and students, in addition to the important role and function of the principal is to be the mobilizer of all available school resources, so that it can be utilized to realize school goals.

\section{The direct relationship between teacher's work motivation and discipline}

The results of the path analysis between teacher work motivation and achievement of State Elementary School in Takisung Sub-district showed a figure of 0.824 , which means there is a high or strong relationship between them.

Motivation is interpreted as the strength or energy of someone, which leads to a level of persistence and enthusiasm originating from inside and outside the individual (Wahjosumidjo, 2013). An individual's motivation greatly determines the behavioral quality displayed in learning, working, and other life activities.

The provision of education in schools requires the high motivation to realize the adequate work discipline of teachers. In the teaching and learning process, motivation is one of the factors that strongly influence learning outcomes. Highly motivated workers are expected to obtain good learning outcomes, which are an important factor in achieving teacher work discipline. Teachers with high motivation tend to carry out faster activities than those with less work motivation (Prayitno et al., 2017).

The direct relationship between the principal's leadership role with teacher's work discipline through motivation

The path analysis results between the principal's leadership role and the teacher's work discipline through work motivation were 0.634 , which means that there was a significant but moderate relationship between the variables.

The results of this study are in line with Sastrohadiwiryo (2016), research which stated that the development of employee work discipline is developed through leadership, which is a role model for subordinates. Therefore, the agency needs to foster the work discipline of employees for early arrival or face full consequences. Furthermore, agency uniforms and other regulations need to be obeyed.

\section{The indirect relationship between maturity of subordinates and teacher's work disci- pline through motivation}

The results of the path analysis between the subordinate maturity and the teacher's work discipline through the motivation of teachers showed 0.605 , which means that there was a significant but moderate relationship between these variables.

Those with a high level of maturity tend to possess a positive impact on behavior in carrying out tasks through motivation to produce high work discipline. It means that the higher the level of maturity of an organization member, the greater the work motivation and discipline in carrying out each job. The results of this study are in line with the study of Syarwani (2018) that indirectly the work discipline of teachers which is one form of school community behavior is influenced by work motivation. Likewise, the maturity of subordinates which can indirectly contribute to the work discipline of teachers, given the higher level of maturity of a subordinate, of course, it will cause the work discipline of the subordinates to be good be- 
cause high maturity of subordinates will encourage the emergence of high work motivation as a form of realization of the ability and willingness of the subordinates concerned to carry out their duties and responsibilities properly

\section{Conclusion and Recommendation}

The role of the principal's leadership, subordinate maturity, work motivation, and discipline of teachers at State Elementary Schools in Takisung Sub-district was included in the moderate category.

There was a high or strong relationship between the principal's leadership role, discipline, and subordinate maturity with the work motivation of teachers.

Furthermore, there was a significant but moderate relationship between subordinate maturity, principal's leadership, and the work discipline of teachers of State Elementary Schools in Takisung Sub-district.

The results of this study are expected to provide benefits for teachers in an effort to provide input to recognize aspects of leadership and work motivation so that teachers can improve their work discipline

\section{Acknowledgment}

This work was financially supported by Research Center for Biomaterials through "DIPA 2017". Therefore, we are grateful for this funding and support of this research.

\section{References}

Aslamiah, \& Irawati, A. (2019). relationship between principal role, work motivation and job satisfaction with elementary school teacher performance. Journal of K6, Education and Management, 2(2), 87-96.

Aslamiah, Sundari, \& Ngadimun. (2019). The influence of leadership, work climate and spirit on discipline elementary school teachers in Batu ampar district tanah laut regency. Journal of K6, Education and Management, 2(2), 78-86

Hoy, W. K., \& Miskel, C. G. (2014). Administrasi Pendidikan: Teori, Riset, dan Praktik. Yogyakarta: Pustaka Pelajar

Jajang, A., \& Mahri, W. (2011). Kepemimpinan kepala sekolah pengaruhnya terhadap kompetensi, motivasi dan kepuasan kerja guru serta implikasinya terhadap kinerja guru. Bandung: UNPAD.
Kartono, K. (2016). Pemimpin dan kepemimpinan. Depok:Raja Grafindo Persada

Maslow, A. H. (2016). Motivation and personality. Jakarta: Erlangga.

Moenir. (2012). Masalah-masalah dalam belajar. Yogyakarta: Pustaka Pelajar.

Nawawi, H. (2015). Manajemen sumber daya manusia untuk bisnis yang kompetitif. Yogyakarta: Gajah Mada University Press.

Prayitno, M. A., Wijaya, N., \& Mursiti, S. (2017). Penerapan modul kimia berpendekatan chemoentrepreneurship untuk meningkatkan kecapakan hidup dan motivasi belajar. Journal of Innovative Science Education, 6(2), 1-9.

Purwanti, S. (2013). Peran kepemimpinan kepala sekolah dalam eningkatkan disiplin kerja guru dan pegawai Di SMA Bakti Sejahtera Kecamatan Kongbeng Kabupaten Kutai Timur. eJournal Administrasi Negara, 1(1), 210-224.

Rahmawati, E., Ahmad, K. I., \& Suriansyah, A. (2019). Relationship Between Emotional Intelligence, Spiritual Intelligence and Teacher Performance Through Work Motivation as Intervening Variable in Islamic Elementary School In Banjarmasin, Indonesia. European Journal of Education Studies, 5(11), 142-160.

Rivai, V. (2014). Manajemen sumber daya manusia untuk perusahaan dari teori ke praktek. Yogyakarta: Raja Grafindo Persada.

Sabirin. (2012). Perencanaan kepala sekolah tentang pembelajaran. Jurnal Tabularasa PPS UNIMED, 9(1), 111-128.

Samsudin, S. (2014). Manajemen sumber daya manusia. Bandung: Pustaka Setia.

Sastrohadiwiryo, S. (2016). Manajemen tenaga kerja Indonesia. Yogyakarta: Bumi Aksara.

Septiana, R., Ngadiman, \& Ivada, E. (2013). Pengaruh kepemimpinan kepala sekolah dan motivasi kerja terhadap kinerja guru SMP Negeri Wonosari. Jupe-Jurnal Pendidikan Ekonomi, 2(1)., 1-10.

Soeharto, K. (2016). Teknologi Pembelajaran. Surabaya Intelectual Club.

Suhaimi. (2019). Relationship of transformational leaders of principal, teacher motivation, teacher organization commitments with performance of primary school teachers in Labuan Amas Selatan. European Journal of Education Studies, daring, 123-141.

Suriansyah, A. (2018). Contribution on supervision of supervisor, principals motivation, kindergarten teacher performance to improving the kindergarten quality in West Banjarmasin, Indonesia. Banjarmasin: Lambung Mangkurat University.

Sutrisno, E. (2016). Manajemen sumber daya manusia. Jakarta: Kencana Prenanda Media Group 
K Nisa, Aslamiah, Suhaimi, 2019 / Relationship between principal's leadership role, subordinate maturity

Suwatno, \& Priansa, D. (2016). Manajemen SDM dalam organisasi publik dan bisnis. Bandung: Alfabeta

Syarwani, A. (2018). The influence of principal leadership style, organizational citizenship behavior, and work motivation on the performance of teachers of State Vocational High
School in Banjarmasin City. International Journal of Scientific Development and Research (IJSDR), 3(11), 8-15.

Thoha, M. (2015). Kepemimpinan dan manajemen. Yogyakarta: Rajawali Press.

Wahjosumidjo. (2013). Kepemimpinan dan motivasi. Surabaya: Ghalia Indonesia. 